\title{
Psychological Well-Being: The Impact of Student Perceptions on Guidance and Counseling Teachers
}

\author{
Luky Kurniawan, Dhanang Suwidagdho, Ruly Ningsih \\ Universitas Mercu Buana Yogyakarta, Indonesia \\ dhanang@mercubuana-yogya.ac.id
}

Submitted : 29-11-2020, Revised : 29-04-2021, Accepted : 29-05-2021

\begin{abstract}
The increasingly complex problem becomes a challenge for guidance and counselling teachers or counsellors as professional helpers. The ideal guidance and counselling teacher or counsellor figure is expected to answer the challenges of the current millennial era. The objectives to be achieved in this study are to obtain an overview of students' perceptions of the ideal guidance and counselling teacher and to find out the relationship between student perceptions and the level of welfare of Senior High School students. The research subjects of Senior High School students in Yogyakarta. The object of this research is, Perceptions of students, Figure of ideal guidance and counselling teachers, The level of well-being of students at Senior High School students in Yogyakarta. The method used for data collection using a questionnaire. The results showed a significant relationship between student perceptions of guidance and counselling teacher figures with the level of psychological well-being in schools. The counsellor's ability to understand himself and see a problem from the point of view of others will have an impact on students' perceptions of the counsellor. These results imply the importance of guidance and counselling teachers to continue to develop professionalism in schools so that students can be served well, and have an impact on the psychological well-being of students.
\end{abstract}

Keywords: Guidance and Counseling Teachers; Psychological Well-Being; Student Perceptions

\section{Introduction}

Indonesia is a developing country with much reliable potential, starting from its geographical location, abundant natural resources, and significant human resources. Indonesia can compete with developed countries by utilizing its potential. The strategic potential that can be exploited is the human resource sector, wherein in 2020 Indonesia has approximately $50 \%$ of the millennial generation of productive age, while in 2030, the productive age is estimated to reach 70\% (Lalo, 2018:s74). In 2030, it is predicted that Indonesia will experience a demographic bonus, in which the number of productive age population (aged 15-64 years) is greater than the population of non-productive age (aged under 15 years and over 64 years). Indonesia can take advantage of the demographic bonus by maximizing the availability of human resources of productive age through improving the quality of education and skills (Afandi, 2017). The National Education System Law Number 20 of 2003 outlines that education is a conscious and planned effort to create an atmosphere of learning and the learning process so that students actively develop their potential to have religious-spiritual strength, self-control, personality, intelligence, noble character, and skills needed by himself, society, nation and country. The National Education System is an integrated whole component of education to achieve the goals of national education.

One of the components of education is the guidance and counselling teacher or counsellor. The existence of guidance and counselling teachers or counsellors in the national education system is stated as one of the qualifications of educators. The guidance and counselling teacher or counsellor as one of the educators has a unique context of the duties and performance expectations of the guidance and counselling teacher or counsellor. Performance expectations of guidance and counselling teachers or counsellors are distinguished by the level of education served informal education, from kindergarten, primary school, secondary school to higher education, each of which has its own needs. In line with the performance expectations 
of guidance and counselling teachers/counsellors in schools, the research results of Zalaquett (2005) found that principals considered the presence of a counsellor to have a positive impact on the academic development, behaviour, and mental health of their students. In addition, most principals indicated that school counsellors recommended school counsellors as one of the career options.

Guidance and counselling teachers/counsellors as helper professionalism schools need to continue to improve their capacity to serve students well. Essential for guidance and counselling teachers/counsellors to continue developing professional identity through learning experiences (Kamore \& Tiego, 2015). Besides developing their professional identity, school guidance and counselling teachers/counsellors also need to differentiate between their primary and additional tasks. The findings of Chandler et al. (2018) identified that sometimes there are still several other tasks outside of the main tasks assigned to school counsellors, including coordinating examinations, schedules, or registration. In addition to problems regarding teacher assignments, another phenomenon that also influences views on the performance of guidance and counselling teachers is the problem of guidance and counselling officers' resources.

Professional educators carry out guidance and counselling as professional services in academic units, namely, counsellors or guidance and counselling teachers. Guidance and counselling teachers are educators with minimum academic qualifications of undergraduate education in guidance and counselling and have competence in guidance and counselling. At the same time, the counsellor is someone with a Bachelor of Education academic qualification in guidance and counselling. It has passed the Professional Education Guidance and counselling Teacher or a counsellor (Regulation of the Ministry of Education and Culture of the Republic of Indonesia Number 111, 2014, Concerning Guidance and Counseling Services in Primary and Secondary Education, 2014).

Academic qualifications and competencies that are determined, academic qualifications and competencies are gradually improved to reach the specified standards as stipulated in Permendiknas Number 27 of 2008 concerning Academic Qualification Standards and Counselor Competencies. Counsellor's academic and professional qualifications can be mapped and formulated into pedagogical, personal, social, and professional competencies. Guidance and counselling teacher figures or ideal counsellors are educators with minimum academic qualifications of undergraduate education in guidance and counselling and have competence in the field of guidance and counselling according to the qualification standards of Indonesian counsellors. Guidance and counselling teachers or counsellors in schools are expected to internalize and develop the competencies so that the guidance and counselling services provided to counselees can run optimally.

The flow of professional education for guidance and counselling teachers in the Indonesian context has been designed in such away. However, the research results by Sapriandi et al. (2018) still, find guidance and counselling officers with non-guidance and counselling backgrounds. The results of this study also identified guidance and counselling officers with non-guidance and counselling educational backgrounds, both pedagogically, professionally, socially, personally, and the ability to understand students, design and implement services, and evaluate the results of service implementation, which are deemed lacking. Inadequate support from various stakeholders also affects the implementation of guidance and counselling. These phenomena can affect student assessments of guidance and counselling teacher figures. Other studies have shown a positive and significant relationship between counsellors' perceptions and students' interest in counselling services (Volungis \& Goodman, 2017). Perceptions of ideal guidance and counselling teachers contributed $28.4 \%$ to the interest in counselling and $71.6 \%$ due to other variables. 
The reality on the ground shows that not all of them align with the conditions described above. Based on the results of observations made by researchers, it was found that most of the guidance and counselling teachers were confined to administrative activities. There were similarities in the guidance and counselling program with the previous year so that it indicated that the guidance and counselling teachers had not optimally developed the guidance and counselling program, most of the guidance and counselling in carrying out individual counselling still seems to advise and has not used an appropriate approach. Another finding is that most of the guidance and counselling teachers' time is spent serving students with problems so that students who excel do not get preservative services.

Guidance and counselling teacher figures that are unpleasant, depressing, and boring (school police) will result in patterns of students reacting negatively, such as stress, boredom, loneliness, isolation, and depression. Experience in less fun school can be a source of significant stress and reduce the quality of life for students (Huebner \& McCullough, 2000). This condition will have an impact on students' assessment of the guidance and counselling teacher or counsellor. The well-being of students can be seen from their assessment of guidance and counselling teacher figures or counsellors, how the role of guidance and counselling teachers or counsellors in the process of facilitating students to achieve personal, social, learning, and career development tasks. Meeting the needs of students and the reciprocal relationship between teachers and students can improve mental health (Wyn et al., 2000). This shows that well-being has an essential role in developing the character of students.

Several studies have been carried out about well-being, such as how psychological wellbeing relates to conflict activity styles (Ümmet, 2020). The finding that self-efficacy has a significant effect in the form of a negative correlation to psychological well-being (Akfirat, 2020; Katsantonis, 2020). Psychological well-being had a significant positive effect on physical activity (Aydin, 2019). Other research results, psychological well-being was correlated highly with life satisfaction (Kaya \& Çenesiz, 2020).

In the current millennial era, the challenge for guidance and counselling teachers is not getting more straightforward but more complex. The rapid development of 21st-century technology creates a life order for students. Technological developments and globalization can directly or indirectly influence the moral development of students. In the millennial era, students began to leave conventional living standards and were replaced by modern lifestyle (Aisyah et al., 2020). The modernization lifestyle today has a positive impact as well as a substantial negative impact. The positive impact is an active contribution to the world of science, information technology, and civilization's advancement, while the negative impact is that most students experience moral degradation, cyberbullying, etc. This increasingly complex problem becomes a challenge for guidance and counselling teachers or counsellors as professional helpers. The ideal guidance and counselling teacher or counsellor figure is expected to answer the challenges of the current millennial era. Based on the explanation above, it is deemed necessary to research to determine students' perceptions of ideal guidance and counselling teacher figures and the level of well-being of students of Senior High School in Yogyakarta City.

\section{Methods}

This research uses a quantitative approach with the type of causality. The data that has been collected is then analyzed at the product moment to determine the level of the relationship between the independent variables and the dependent variable. Researchers collect data using a questionnaire involving several random samples without action, so this research is also called survey research. 
The population of this research includes Senior High School in Yogyakarta City. The sampling technique used was proportionate stratified random sampling. The characteristics of the strata in the population are considered in determining the sample because the experience and intensity of students in school will colour the students' perceptions of the Guidance and Counseling teacher/counsellor figure. The number of samples in this study was 70 students in Yogyakarta City. Data collection was carried out by asking respondents to fill out a questionnaire prepared by the researcher using Google Forms. The scoring guideline on the questionnaire refers to the Likert scale. The range of answers used is 1 (very inappropriate) - 4 (very suitable). If the respondent feels that the statement presented describes himself / following his condition, he answers "very suitable." In contrast, if the respondent feels that the statement is not according to his condition, the respondent gives a sign $(\sqrt{ })$ in the column "very inappropriate."

The data that has been collected is then tabulated to facilitate analysis. The analysis used to answer the hypothesis is the analysis Pearson product-moment correlation. Analysis was performed with the help of SPSS for Windows 22.00 Version.

\section{Results and Discussion}

The fundamental issue that is the challenge in this research is the Covid-19 pandemic. This extraordinary phenomenon requires researchers to adapt and choose to collect data with the help of Google Forms. The process carried out by researchers was changing the instrument items into digital format, distributing these instruments to partner schools, and then passing them on to students.

Seventy-eight students filled in the instrument items but then reduced it to 70 students who met the criteria in this study. Based on the research data, it can be seen that the minimum score obtained by students on the perception variable is 50 and the welfare variable (wellbeing) is 39. While the maximum score is 79 for the perception variable and 62 for the welfare variable, respectively. This difference in score is also influenced by the number of different statement items for each variable, namely 22 items for the perception variable and 18 items for the variable well-being. Data normality testing was carried out with the help of SPSS version 15 using the formula Kolmogorov-Smirnov2. It can be seen that the significance value of the perception variable is $0.547>0.05$ and the well-being variable is $0.088>0.05$ so that it can be concluded that the data is normally distributed. The research data were then tested using SPSS version 15 to see the correlation using the analysis Pearson product-moment presented in Table 1.

Table 1. Analysis Pearson Product Moment

\begin{tabular}{llcr}
\hline & & Perception & Welfare \\
\hline Perception & $\begin{array}{l}\text { Pearson } \\
\text { Correlation }\end{array}$ & 1, & $415(* *)$ \\
\hline & Sig. (2-tailed) & &, 000 \\
\hline Well-being & $\begin{array}{l}\text { Pearson } \\
\text { Correlation }\end{array}$ &, $415(* *)$ & 1 \\
\hline & Sig. (2-tailed) &, 000 & \\
\hline
\end{tabular}

The data in table 1 . shows the value, $r=0.415$ and Sig. $0.00<0.05$, so it can be concluded that there is a significant relationship that there is a positive and significant relationship between student's perceptions of the ideal guidance and counselling teacher or counsellor figure with the level of well-being of students of Senior High School. This means 
that the more positive perceptions the students' guidance and counselling teacher or counsellor figure, the higher the students' level of well-being. Research shows, in general, students perceptions of teacher professional competence guidance and counselling regarding mastering assessment concepts and praxis to understand students' conditions, needs, and problems at Seven State Junior High School, Padang are classified as good (Rosa et al., 2016).

Perception is coloured by one's life experience, which will colour how a person exercises control over actions (Zacks, 2020). Positive perceptions will make an individual feel comfortable, prosperous, and satisfied so that they can function optimally. The positive perceptions of students in schools of guidance and counselling teachers as figures who are expected to be good listeners when students face problems will determine their psychological well-being while studying at school.

Some factors influence students' perceptions of tutoring and counselling teachers, namely service quality, situation factors, personal factors, counsellor mastery and curriculum. Personal factors are related to individual characteristics. This is supported by research that says that a professional school counsellor is not enough just to master the concepts, theories, and techniques of counselling, but also must have pleasant characteristics to create an atmosphere of close relationship with students (Yuan, 2017).

The personal counselling teacher/counsellor is a very determining factor in the success of guidance and counselling services in schools. In addition to mastery of science and skills that must be possessed by a counsellor, personality guidance and counselling teacher/counsellor who is attractive and able to make students feel comfortable very important. Regardless of the quality of the curriculum design or guidance program and the counselling that was made, all of which would be useless if the teacher. The counsellor is unable to present a warm, friendly, and nurturing personality in the implementation of guidance and counselling in schools. Counsellors need to build rapport with students where the counsellor tries to make students comfortable with caring about the problems that students are experiencing and does not focus on whether our students like us or not, our abilities listening, empathy, and not judging learners (Kennedy \& Charles, 2017).

The ideal personal counsellor/counsellor is needed for the successful implementation of guidance and counselling services in schools. The meaning is ideal indeed subjective depending on the point of view of each. Personal counselling teacher/counsellor The ideal is an ability that the counsellor should have in assisting his duties as a counsellor. This is because the success of a helper is closely influenced by his ability to understand yourself and see a problem from the perspective of others. Guidance and counselling teacher/counsellor is a person who can form relationships that are of a nature collaborative in helping students based on pedagogical competencies, personable, social, and professional. The findings in this study further emphasize the importance of guidance and counselling teachers to continue to develop their professionalism in schools so that students can be served which has an impact on their welfare at school.

\section{Conclusions and Suggestions}

Based on the results of the research that has been carried out, it is known that there is a significant relationship between student's perceptions of the guidance and counselling teacher and the level of psychological well-being of students in schools. This result implies the importance of guidance and counselling teachers to continue to develop their professionalism in schools so that students can be served, which has an impact on their welfare at school. 
Suggestions based on the research results are that guidance and counselling teachers can continue to improve their professionalism and provide the best service for students. This professionalism and service will later form a positive self-image and perception of students towards guidance and counselling services. For future researchers, it is hoped that they can research and find the most appropriate strategies applied by guidance and counselling teachers to increase positive perceptions of students.

\section{References}

Birenbaum, M., Alhija, F. N.-A., Shilton, H., Kimron, H., Rosanski, R., \& Shahor, N. (2019). A further look at the five-dimensional curiosity construct. Personality and Individual Differences, 149, 57-65.

Blakemore, S.-J. (2018). Avoiding social risk in adolescence. Current Directions in Psychological Science, 27(2), 116-122.

Blatterer, H. (2020). Friendship and solidarity. European Journal of Social Theory, 1368431020982499.

Díaz, A., Gómez, M., \& Molina, A. (2017). A comparison of online and offline consumer behaviour: An empirical study on a cinema shopping context. Journal of Retailing and Consumer Services, 38, 44-50.

Firdhani, A. M. (2021). Peningkatan Kemampuan Musikal Peserta Didik Melalui Aktivitas Musik Kreatif. Indonesian Journal Of Performing Arts Education, 1(1).

Haryani, O., Huda, S., \& Topan, A. (2013). Kesenian Sarafal Anam Dan Nilai-Nilai Yang Terkandung di dalamnya pada Masyarakat Lembak dalam Adat Istiadat (Studi Kasus di Kelurahan Dusun Besar Kecamatan Singaran Pati Kota Bengkulu). Universitas Bengkulu.

Hermino, A., \& Redjeki, D. S. S. (2020). The Importance of Character-Based Health Education in School to Improve Quality of Health Living in Indonesia. Asian Social Science, 16(10).

Holschuh, J. P. (2019). College reading and studying: The complexity of academic literacy task demands. Journal of Adolescent \& Adult Literacy, 62(6), 599-604.

Hosnan, M. (2014). Pendekatan saintifik dan kontekstual dalam pembelajaran abad 21: Kunci sukses implementasi kurikulum 2013.

Kim, B., \& Kim, S. S. (2018). Hierarchical value map of religious tourists visiting the Vatican City/Rome. Tourism Geographies.

Kim, S. H., \& Seock, Y.-K. (2019). The roles of values and social norm on personal norms and pro-environmentally friendly apparel product purchasing behavior: The mediating role of personal norms. Journal of Retailing and Consumer Services, 51, 83-90.

Liu, L., Xu, L., Xiao, X., Liu, L., \& Li, Y. (2020). Positive influence of peers' interpersonal character on children's interpersonal character: The moderating role of children's and peers' social status. Journal of Adolescence, 79, 157-172. 
Nichols, J. R. (2015). Four Essential Rules of 21st Century Learning.

Oktavianti, I., Zuliana, E., \& Ratnasari, Y. (2017). Menggagas kajian kearifan budaya lokal di sekolah dasar melalui gerakan literasi sekolah. Kudus: Universitas Muria Kudus.

Omeri, N. (2015). Pentingnya pendidikan karakter dalam dunia pendidikan. Manajer Pendidikan, 9(3).

Sari, P., \& Bulantika, S. Z. (2019). Konseling indigenous berbasis tata nilai budaya lampung "piil pesenggiri " dalam pembentukan. 9(2), 190-199.

Sari, P., Suryawati, C. T., \& Bulantika, S. Z. (2020). Internalisasi Nilai-nilai Piil Pesenggiri untuk Mencegah Perilaku Bullying Siswa SMK. 6(1), 1-7.

Sari, P., Triyono, T., \& Mappiare, A. (2018). Panduan Pertimbangan Nilai Ajaran Nengah Nyappur Etnis Lampung untuk Mereduksi Perilaku Bullying Siswa SMK. Jurnal Pendidikan: Teori, Penelitian, Dan Pengembangan, 3(8), 1095-1099.

Schneiderman, J. U., Kennedy, A. K., Granger, T. A., \& Negriff, S. (2020). Predictors and correlates of unstable housing experiences among a child welfare-involved sample. Journal of Public Child Welfare, 14(2), 192-208.

Sudjono, E. T. K., \& Kusumastuti, E. (2017). Proses Pembelajaran Gerak dan Lagu yang Kreatif Berdasarkan Kurikulum 2013 di TK Miryam Semarang. Jurnal Seni Tari, 6(2).

Tarobin, M. (2015). Seni "Sarafal Anam" di Bengkulu: Makna, Fungsi dan Pelestarian. Jurnal Bimas Islam, 8(2), 265-296.

Van Der Schyff, D., Schiavio, A., Walton, A., Velardo, V., \& Chemero, A. (2018). Musical creativity and the embodied mind: Exploring the possibilities of $4 \mathrm{E}$ cognition and dynamical systems theory. Music \& Science, 1, 2059204318792319. 
